\title{
Research on Overseas Knowledge Property Protection Strategy of Chinese Enterprises
}

\author{
Hua Gao ${ }^{1, a}$ \\ ${ }^{1}$ School of Economic and Management, Wuhan University, Wuhan 430072 \\ axth6800@163.com
}

Keywords: Overseas intellectual property, Risk identification, Coping strategy.

\begin{abstract}
After China joined the WTO, more and more Chinese enterprises began to go abroad. But the "going global"process of Chinese enterprises is frequently accompanied by various intellectual property risks, which has already become the bottleneck hindering Chinese enterprises' going global. This paper analyzes different types of intellectual property risk of Chinese enterprises, provides process of patent infringement risk aversion, and discusses intellectual property aid mechanism.
\end{abstract}

\section{Introduction}

After China joined the WTO, more and more Chinese enterprises began to go abroad, and actively participate in international competition. China's booming foreign trade business has affected the development of export destination countries, and therefore, more and more multinational companies limit Chinese enterprises to participate in international competition and overseas development through trade barriers (anti-dumping, anti-subsidy) and intellectual property barriers (337 investigations, litigation, other intellectual property disputes overseas). So, Chinese enterprises overseas rights have become an inevitable issue for foreign trade companies to give enough attention.

With the "going out" strategy further promotion, a large number of enterprises represented by Huawei, ZTE, Lenovo etc, go overseas, actively participate in international competition on a global scale, and integrate into international industrial system through foreign investment, cross-border mergers and acquisitions and other ways. By the end of 2011, China has set up 13,500 overseas enterprises in 177 countries and regions through direct investment. The amount of foreign investment is rough $\$ 424.8$ billion, ranking the $13^{\text {th }}$ of the world. Chinese enterprises frequently encountered intellectual property disputes while obtaining huge economic benefits. In the first three quarters of 2012, China's exports suffered 55 trade remedy investigations from abroad with an increase of $38 \%$, involving 24.3 billion yuan.

With the Sino - American bilateral trade increasing rapidly in recent years, the number of American Section 337 investigation against China grows annually. China has become the main target of the investigation. It has become the most incisive weapon, bringing great harm to exporting enterprises of our country.

As a scarce resources containing huge commercial value, intellectual property undisputed become the core strategic resources of multinational firms survival and development, and the core elements for enhancing competitiveness. Due to small scale, weak ability to withstand risks, China's enterprises are more liable to intellectual property infringements. Chinese export loss caused by technology trade barrier are increasing annually(Fig 2).

In this paper, based on the background of going out, we aim to establish a system of the intellectual property rights overseas aid mechanism to provide references for enterprises to successfully deal with intellectual property(patents, trademarks, etc) risks. The remaining structure of this paper is organized as follows: Section 2 identify risk type. Section 3 discusses patent infringement risk aversion. Section 4 provides some corresponding Strategy. 


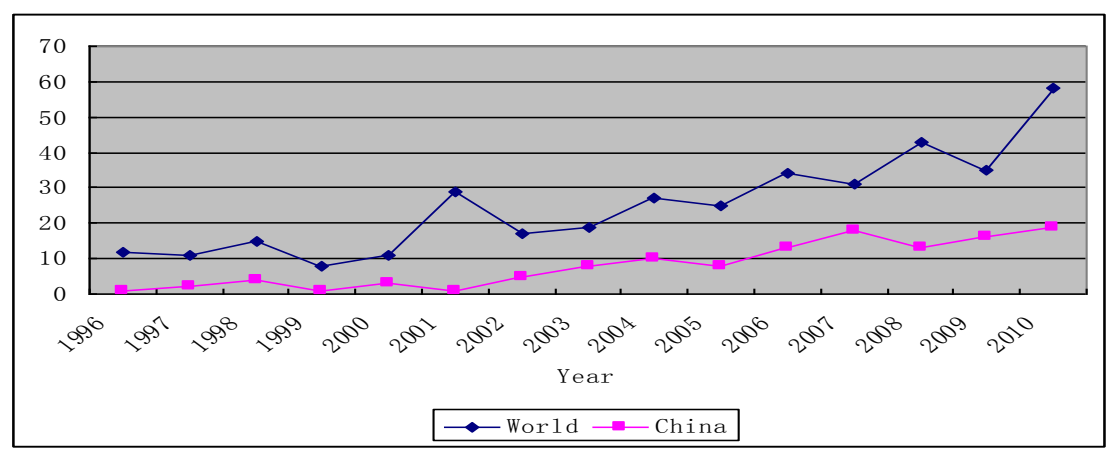

Data source: http://www.usitc.gov/; http://www.mofcom.gov.cn/

Fig. 1 Section 337 investigation of the world and China

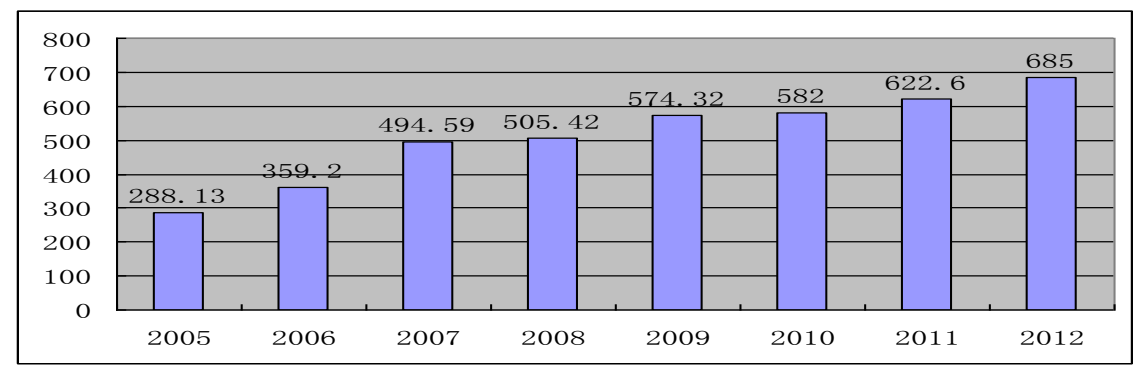

Fig. 2 China export loss caused by technology trade barrier(100 million dollars)

\section{Overseas Intellectual Property Risk Identification}

\section{Type I: The risk of trademark overseas operations}

Overseas trademark applications Risk.A typical example is the English trademark of Lenovo "LEGEND" suffered too much conflict in application process overseas. Lenovo had to abandon the "LEGEND" trademark in 2005 and be replaced by "LENOVO" trademark. The loss of trademark replacement is very much. The reason is that LEGEND is a too common English word, and there are too many overseas companies already applied for this trademark.

Overseas trademark registered Risk. The typical example of overseas trademark registered risks is the "HiSense" trademark. When Hisense and other companies ready to enter the German market, they found that "HiSense" trademark has been registered in German by Siemens and had to spend 50 million euros to redeem the trademarks. These type risks are mainly produced by lacking long-term planning when Chinese firms develop overseas market.

Be commissioned to process export products Risk. Another type risk is the infringement risk of be commissioned to manufacture export products for foreign firms. A typical example is that foreign customers commission domestic firms to manufacture foreign brand products that are not sale in the domestic market. So domestic firms think that there is no risk of infringement. However, the goods were detained on suspicion of intellectual property infringement when the goods are out of Customs. Zongshen Corporation who had produce "HONGLEI" brand engine for foreign customers was once seized by export Customs for consideration of violating domestic companies trademark. To avoid such risks, we should ask foreign customers to provide non-infringement commitment and show the relevant authorization certificate for commission processing brand (trademark). In addition, whether in the processing of manufacturing countries or in exporting countries, whether the infringement is established should be retrieved, and the agreement of responsibilities of both parties in the event of infringement should be signed.

\section{Type II: Patent Infringement Risk}

Patent Infringement Risk for goods export. With the increase of Chinese enterprises "going out", exported goods were alleged patent infringement overseas gradually increased. The main way 
for a long period of time, China's trade in goods as "going out", patented technology, especially core patented technology is scared, intellectual property rights awareness is weak, resulting in repeated Chinese enterprises overseas patent clamp. A typical example is DVD industries.

DVD was once the pride of the Chinese electronics industry. The price of each DVD produced in Europe is just over 100 euros, far less than the local product prices which are around 500 euros each. Due to Chinese DVD industry growing, the overseas DVD patentees start to be "pain killers." In November 2000, DVD patent pool 6C combined by Toshiba, Panasonic, JVC, Hitachi and other companies introduced "DVD patent license Incentive Plan" and have a formal negotiation with Chinese DVD enterprises about royalties payment. In April 2002, 6C make an agreement with China Audio Industry Association: Chinese companies should pay $\$ 4$ for royalties when export every DVD player. This leads to the cost of DVD player increasing drastically and the loss of international competitive advantage.

Overseas exhibitions infringement risk. Another kind of Patent Infringement is overseas exhibitions infringement risk. A typical example is the recent electronics trade fair in Hanover, Germany. Chinese enterprises such as Huaqi Patriot, Newman and other digital products manufacturers who made MP3 were alleged patent infringement of Italy's Sisvel patent (detained).

\section{Type III: The risk of Intellectual Property Barriers Abroad}

Because the traditional trade barriers is restricted by international treaties, other countries, especially developed countries, often set unreasonable barriers to goods, technique and investment involving intellectual property in the name of intellectual property rights protection or by virtue of its intellectual superiority. Reasonable control of the core patents, unequal terms of trade, discriminatory prices etc. will bring the international competitiveness risk for Chinese enterprises.

Wenzhou lighter case is the first patent barriers encountered by WTO members who set the block threshold in the field of international trade after China joined "WTO". At present European lighter enterprises have applied a lot of "safety lock" patent, while Wenzhou enterprises research space has been squeezed by "patent barriers". Thus, if you can not develop your own patent, Wenzhou lighter industry will have to spend exorbitant prices to buy foreign patent, and the cost of their products will drastically increase and competitive advantage will be lost.

\section{Type IV: The Risk of Abuse Complaints Overseas Competitors}

Foreign competitors may bring intellectual property infringement litigation against China "going out" enterprises in order to damage the reputation of Chinese enterprises and exclude Chinese enterprises to enter foreign market even though there are little possibility for win in the facts and the law. Coupled with the existence of such "337" and other complaints of the rights and obligations of the extreme inequality appeals process, these also contributed to foreign competitors abuse complaints. High costs for overseas responding and psychological fear tends to keep Chinese companies away from this court, which is likely to hear only the story of plaintiff's and make its decision that is not conducive to China's party. Domestic enterprises may therefore give up their "going out" program, which is the result that abuse complaints wants.

\section{Type V: Domestic and International Intellectual Property Laws Inconsistent Risk}

Due to the inconsistency of domestic and foreign intellectual property legal system and not understanding legal norms of foreign markets, the domestic enterprises are usually in a passive position during entering foreign markets. Although the international intellectual property system integration trend is increasingly evident, intellectual property law system of each country has its characteristics. The relative lack of legal talent related to foreign affairs makes companies unable to understand foreign laws and regulations and deal with overseas intellectual property disputes effectively. The benefits will be lost with slightly ignorance. These laws reefs have become obstacles to going abroad business.

A typical example is Cape company in Zhejiang which produces digital generators and other machines was filed 337 patent infringement investigation by American Honda through the US Trade Commission (ITC) in September 2006. Another case is the Lifan Group who produces gasoline 
engines was also sued by Honda to the US District Court on the ground of unfair competition. Both cases are related to general machinery products which are mainly concentrated on the Europe and America market whose intellectual property rights protection is the most stringent in the world. The cumbersome judicial procedures and high litigation costs of Europe and America may prohibit Chinese enterprises enter these markets. Among more ITC Litigation that Chinese companies were accused of patent infringement in the United States, the majority Chinese firms chose to be passive respondent and be sentenced to be default infringement because of absence, resulting in the loss of almost the entire US markets.

\section{Patent Infringement Risk Aversion}

Among all kinds of intellectual property disputes, patent infringement cases occupy a considerable proportion. So it is necessary for us to identify patent infringement risk and know how to cope with patent infringement litigation. Figure 3 gives a process of risk aversion and coping strategies of patent cases.

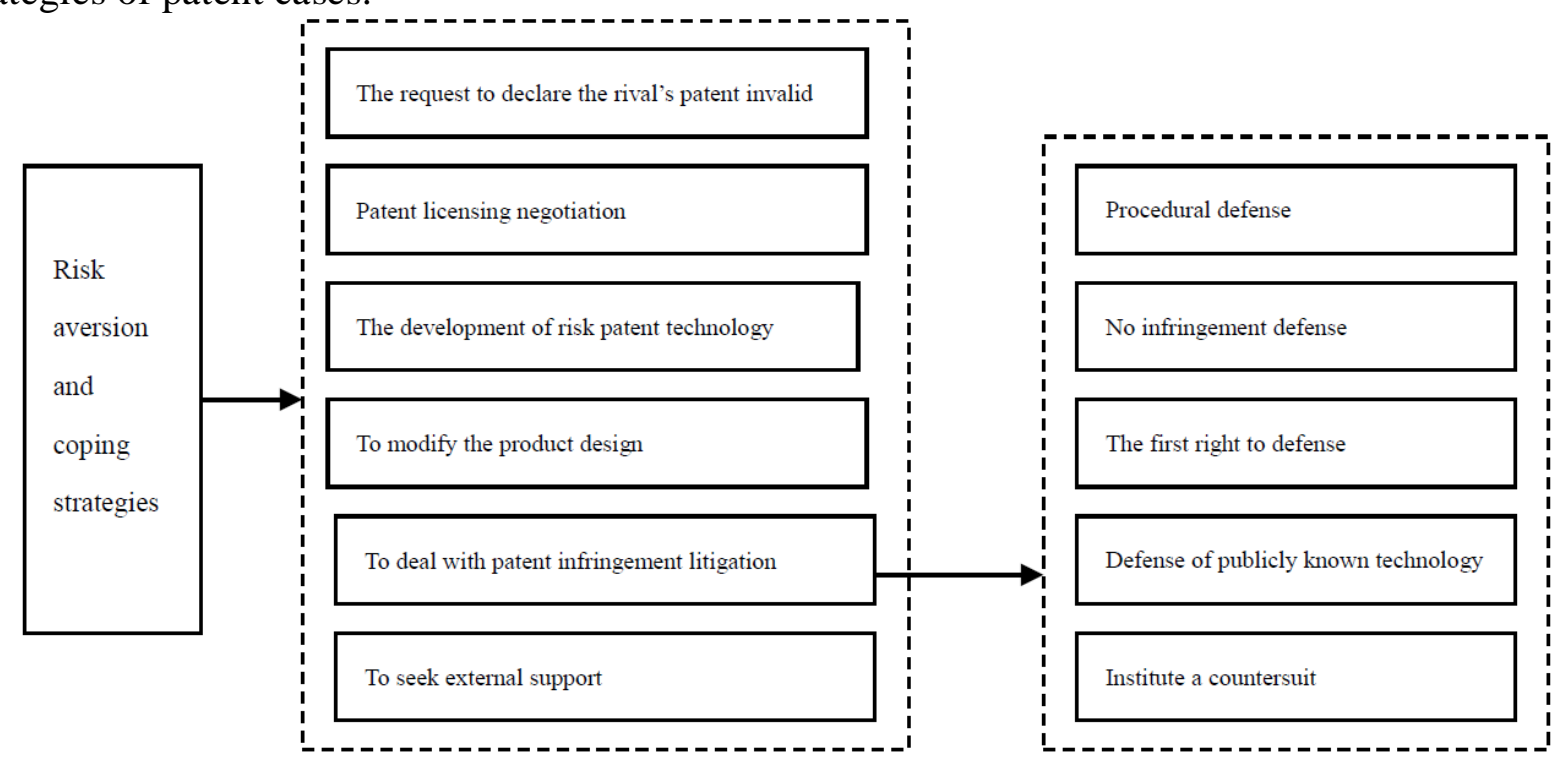

Fig. 3 Process of Risk aversion and coping strategies

If you found that patent infringement risk exists, you can take the initiative to request declaring the rival's patent right was valid. The reason may be that the rival's technical scheme is lack of novelty or creativity, and illegal patent state (duplicate authorization) etc. The invalidation of the patent right make the rival to lose the right to sue their rivals for infringement, which can also provide the foundation for reaching a settlement with the competitors. If enterprise found the infringement risk exist or were suffered infringement litigation, they can actively seek external support, such as industry associations, industry alliance etc.

If enterprises face the patent infringement litigation, they can take following measures:

They can make the procedural defense, including the denial of the qualification of the plaintiff, the denial of the jurisdiction of the Court of Appeal and the statute of limitations, etc.

They can make no infringement defense. According to the basic principles of the patent infringement, they shall collect evidence to prove that the allegedly infringing product does not infringe the risk patent.

They can prove the right of prior use. Prior use right refers to the enterprises has made the identical product, used the identical process, or made necessary preparations for making use of the right to make, use in the original scope before the patent application of the other side.

They could defend public known technology, proving the alleged infringing product is the use of the public known technology. Well-known technology refers to the invention, utility model or design patent that has published at home and abroad, be used use at home and abroad publicly or 
were well-known technologies (design) in other ways prior to the date of patent application.

They can file a counterclaim, analyze whether rival's product falls into the scope of patent right protection of one's own. Once falls into the scope of protection of one's own patent, they can file a counterclaim.

\section{Corresponding Strategy}

The enterprises' overseas intellectual property protection is a systematic engineering. It involves multi-agents, such as firms, government, industry association, financial Institutions etc. and it need the close collaboration of these agents.

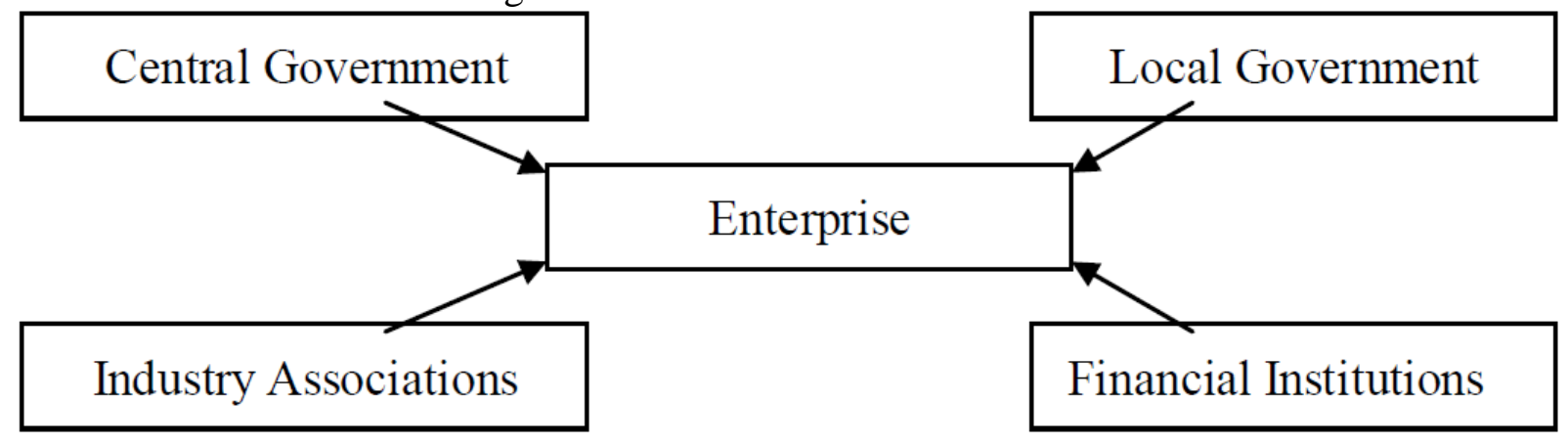

Fig. 4 The enterprises' overseas Intellectual property protection mechnism

\section{Establish and Improve Multi-sectoral Linkage of Intellectual Property Rights Overseas Aid Mechanism Construction}

We should treat overseas intellectual property rights protection as national strategy, and promote collaborative mechanism for corporate overseas intellectual property development assistance centers by the coordination of Foreign Affairs, Ministry of Finance, the State Intellectual Property Office, the Ministry of Commerce and other relevant government departments, and guide local IP assistance center to carry related business of corporate overseas intellectual property aid, provide and support for the corporate overseas intellectual property aid.

\section{Establish Overseas Warning Service Platform for Intellectual Property}

We should establish China's intellectual property rights overseas warning service platform, which can give intellectual property risk warning, have an active prevention and develop contingency plans to help businesses cope with overseas intellectual property disputes from passive coped with to actively faced risks by combining with corporate objectives and market products. Thus improve corporate intellectual property overseas warning mechanism.

\section{Awareness of IP Protection}

The key factor is independent intellectual property during overseas intellectual property safeguard. So firstly, China's enterprises must raise awareness of intellectual property protection, and secondly, grasp foreign intellectual property litigation rules and regulations and avoid the risk reasonably. Enterprises shall fully understand the regional characteristics of intellectual property. As a prerequisite, firms shall make sure that they do have some specific intellectual property rights in the relevant country or region, and make sure whether their competitor has any specific intellectual property right. While intellectual property rights are the rules of markets, either to sue or to respond to other's litigation, firms shall act on the basis of their economic interests. Comparing with many domestic enterprises which have no consciousness of protecting intellectual property rights and take negative measures to the investigation, JK Sucralose Inc of Jiangsu province applied to joining the lawsuit of sucralose case and got sweeping victory.

\section{Establish Overseas Aid Special Funds for Intellectual Property Rights}

We should establish special overseas-funded for IPR protection aid in order to sponsor 
enterprises to develop intellectual property rights for warning and emergency relief, which are mainly for overseas business intellectual property-related information consulting, legal advice and other services to help businesses prevent and respond to overseas intellectual property risks.

\section{The Use of Patent Portfolio to Defuse the Overseas Infringement Risk}

Chinese enterprises should build patent portfolios, and establish a global system to expand foreign market. In fact, Chinese invention patent applications have ranked first in the world for three consecutive years. The number of patents of Chinese enterprises in the US, EU, Japan and other countries and regions are also growing rapidly. A mature patent portfolio should have three roles: as an important part of the company's revenue sources (patent can be used as a profit centers besides traditional business), as the company's current assets (patent liquidity increase can protect shareholder value), product or market protection (defensive tactics).

\section{References}

[1] Bao Zhen-yu, A Study of the Cognition and Corresponding Strategies of Section 337 of U.S. Tariff Act, Research on International Business, 2014(1):65-75.

[2] Li Ping, The Corresponding Tactics of intellectual property barrier between China and America trade, The Economic Aspect, 2011(10):7-11.

[3] Xiao Zhi yong, CHENG Yong mei, Analysis of American Section 337 Investigation against China through JK Sucralose Inc Winning the Law suit of the Sucralose Case, Soft Science, 2010(5): 60-64.

[4] Li Ming de, Several issues involving in protecting the intellectual property in the overseas for Middle and Small firms, Intellectual Property, 2013(1): 70-74.

[5] Zhang Li na, Antimonopoly regulating to misusing IP right of Transnational Corporations-At the angle of Antimonopoly Law, Journal of Guang Xi Administrative Cadre Institute of Politics and Law, 2011(5): 41-44.

[6] $\mathrm{Xu}$ yuan, Challenges and Corresponding Strategies of Patent barrier for China's Export, International Trade, 2014(5): 30-35.

[7]Yao Xin chao, Trend of American Patent barrier and Corresponding ways of Chinese enterprises, International Trade, 2010(9): 59-66.

[8]Gao Hua, Analysis on Judging Standard of Abuse of IP Rights in Field of International Trade: in Context of US Cases, Legislation and TRIPS, International Trade Issue, 2011(10): 159-167.

[9] Dai Xiang, Implementing IP Strategy: the Effective Way for Chinese Enterprises to Cope With the Clause No.337 of American Tariff Law, International Trade Issue, 2006(2): 115-120. 